\title{
Tesla Fights Back
}

\section{Dear Reader,}

Tesla has a new adversary by the name of Donald Trump. The future president of the United States has been known to keep the company of climate contrarians. According to a report that appeared in the German weekly Fokus, however, he is nonetheless planning to build flood barriers around a number of his golf properties. But whatever the president-elect's personal opinion about climate change might be, his campaign promise to review strict vehicle-emissions standards and to work towards a deregulation of the energy sector suggests that his policies could go in favor of the internal-combustion engine.

The contentious billionaire will not, however, hinder the development of electric vehicles. And the Tesla Corporation will remain undeterred as it continues to pursue its stated objectives. The latest move on the part of Elon Musk, the Tesla Corporation's technophile and entrepreneurial founder was to enter into an agreement to acquire the German automated manufacturing firm Grohmann Engineering. The Prüm-based, mediumsized company located in the German state of Rhineland-Palatinate specialises in highly-automated production.

The immediate rationale for the acquisition is Tesla's need to ramp up its production efficiency to accommodate significant increases in its output targets for its expanding fleet of vehicles - not only in the United States and in Germany, but also in China where Grohmann operates an established subsidiary. This latest move on the part of Tesla comes after it already secured the services of Peter Hochholdinger who spent two decades as a production specialist at the Audi Corporation.

At the moment, however, we can only speculate about the full story behind the move. For instance, the fact that Grohmann developed and supplied fully automated production equipment to the
Li-Tec battery-cell production facility in Kamenz, Germany is an interesting detail. Tesla's move could therefore be an attempt to purchase important knowhow relating to a more promising cell design. Up until now, Tesla has relied on large and heavy round cells. These cells can be expected to meet their thermal limitations in the wake of continuing efforts to boost energy density. Like prismatic battery cells, the pouch cells developed by the former German enterprise Li-Tec offer clear advantages.

In the meantime, the German industry is engaged in an extended round of infighting. According to Henning Kagermann, Chairman of the German National Platform for Electric Mobility, industry leaders and other stakeholders will not to reach an agreement in the coming two years on renewed efforts to establish domestic battery cell production. Despite concerted efforts to reach a consensus, differences of opinion on cell types and modus operandi remain. By the time things get sorted out here, Tesla may well already have launched battery production in Germany. While the batteries in question may be based on less-than-perfect cells, they're likely to conform to a healthy pragmatism.

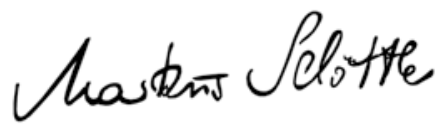

Markus Schöttle

Deputy Editor in Chief

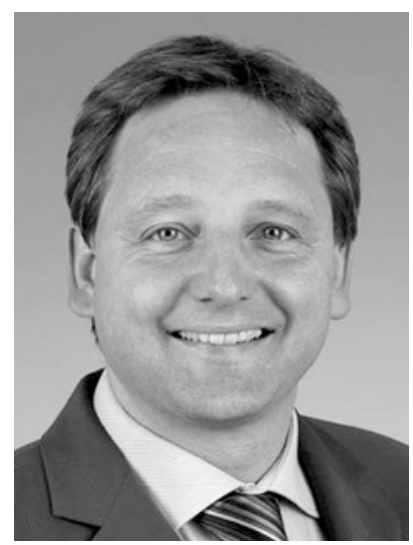

